\section{MINIMALLY-INVASIVE TRANSOBTURATOR CORRECTION OF CYSTOCELE}

\section{CORREZIONE PROTESICA MINIINVASIVA PER VIA TRANSOTTURATORIA DEL CISTOCELE}

\author{
R Baccichet*, C Braghin, A Azzena
}

\author{
OBSTETRICS AND GYNAECOLOGY UNIT, \\ OSPEDALE CIVILE DI CONEGLIANO VENETO, ULSS 7 \\ *UROGYNAECOLOGY DEPARTMENT, OBSTETRICS AND GYNAECOLOGY UNIT, \\ O.C. CONEGLIANO VENETO, ULSS 7
}

\begin{abstract}
Key words: prolapse anterior vaginal wall, cystocele, transobturator foramen, minimally-invasive urogynecological surgery, tension-free technique of mesh,
\end{abstract}

SUMMARY: We present our initial experience with the Perige ${ }^{T M}$ System for correction of prolapse of the anterior vaginal wall. We recruited twenty patients with anterior vaginal prolapse, underwent a prosthetic operation using the Perigee System, which consists of a large-pore, monofilament polypropylene mesh and four lateral arms made of the same material, positioned via the transobturator foramen. This system permits simultaneous correction of central and lateral defects. Prolapse and therapeutic outcome were evaluated using the $P O P-Q$ system. The 20 patients were suffering from grade III cystocele. The follow-up was conducted after six weeks, three months, six months, twelve months and eighteen months. After six weeks and three months the cystocele was
SOMMARIO: Presentare la nostra iniziale esperienza con il sistema "Perigee" per la correzione del prolasso della parete vaginale anteriore. Abbiamo reclutato 20 pazienti con prolasso vaginale anteriore, sottoposte ad intervento protesico con il sistema "Perigee", costituito da una mesh, in polipropilene monofilamento macroporoso, da cui partono quattro bracci laterali costituiti dallo stesso materiale il cui posizionamento avviene per via transotturatoria. Con questo sistema risulta possibile la contemporanea correzione del difetto centrale e di quello laterale. Per la valutazione del prolasso e per la valutazione del successo terapeutico è stato utilizzato il sistema POP-Q. Le 20 pazienti presentavano un cistocele di grado III. Dopo 6 settimane, 3 mesi, 6 mesi, 12 mesi e 
entirely resolved (grade 0 ) in the 20 patients. After six months the cystocele was resolved (grade 0) in 17 patients, while three had grade I cystocele. After 12 months and 18 months the cystocele remain grade $O$ in 16 patients, while four had grade I cystocele. No vascular damage or significant bleeding was observed. Two cases of vaginal erosion and one of de novo urinary incontinence were observed. Our experience appears to show that transobturator prosthetic correction of cystocele represents a safe, effective and reproducible minimally-invasive surgical technique that permits adequate restoration of normal anatomy.

\section{INTRODUCTION}

The prevalence of pelvic floor defects is significant, above all in the 5 th and 6th decades of life, with figures ranging from 15 to 35\% reported in the literature, depending on the series. Specific defects of the pelvic fascia, whether anterior or posterior, can be lateral, medial or transverse. Lateral defects are the result of detachment of the fascia of the tendinous arch of the levator ani which runs from the ischial spine to the pubis, anteriorly, and to the perineal membrane, posteriorly. Medial defects are the consequence of a hernia that develops along the midline of the pubocervical fascia anteriorly and the rectovaginal fascia posteriorly. Transverse defects correspond to a hernia that develops in a supra-vaginal position anteriorly and posteriorly to the uterine cervix, in the space of the an-
18 mesi in 16 pazienti il cistocele è stato risolto completamente (grado O), mentre 4 presentavano un cistocele di grado I. Nessun danno vascolare né alcun sanguinamento significativo sono stati osservati. Si è verficato un unico caso di erosione vaginale ed un caso di incontinenza urinaria de novo. La nostra esperienza sembra dimostrare che la correzione protesica del cistocele per via transotturatoria rappresenti una tecnica chirurgica miniinvasiva sicura, efficace e riproducibile, che consente un adeguato ripristino della normale anatomia.

\section{INTRODUZIONE}

La prevalenza dei difetti del pavimento pelvico è rilevante soprattutto nella $5^{\circ}$ e $6^{\circ}$ decade di vita, con valori molto variabili tra il 15 e il $35 \%$ a seconda delle serie riportate in letteratura. Il difetto specifico della fascia pelvica, sia anteriormente che posteriormente, può essere laterale, mediano e trasversale. Il difetto laterale è conseguente al distacco della fascia dell'arco tendineo dell'elevatore dell'ano che decorre dalla spina ischiatica al pube, anteriormente, ed alla membrana perineale, posteriormente. Il difetto mediano è alla base di un'ernia che si sviluppa sulla linea mediana della fascia pubocervicale anteriormente e della fascia rettovaginale posteriormente. Il difetto trasversale è alla base di un'ernia che si sviluppa in sede sopra-vaginale anteriormente e posteriormente alla cervice 
terior and/or posterior fornix vaginae, due to detachment of the pubocervical fascia (1-2). Reconstructive surgery of pelvic floor defects is changing radically and continuous advances in biotechnology and prosthetic materials that promote the growth of supporting connective tissue have led to the creation and development of minimally-invasive prosthetic surgery in this field (3). Within this new surgical approach, the Perigee System, a new transobturator system for correction of prolapse of the anterior vaginal wall, seems to provide a good illustration of what should be the advantages over more traditional surgery (4-5):

- Minimally invasive

- reduced surgical time

- fewer intra-operative complications

- less intra-operative bleeding

- a more easily reproducible technique

- the possibility of procedural standardisation

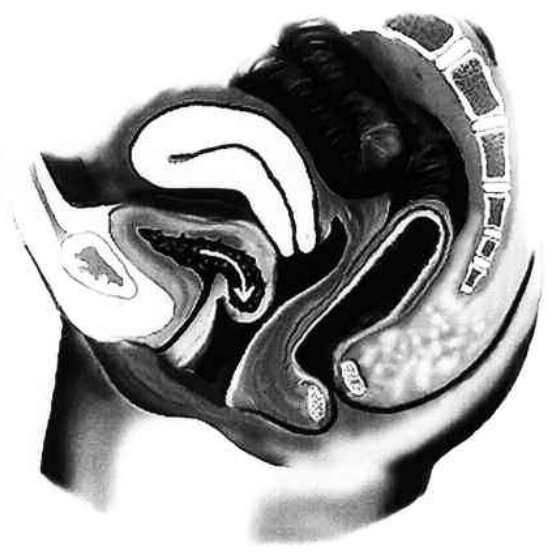

Fig. 1 - Cystocele uterina, nello spazio del fornice vaginale anteriore e/o posteriore, per distacco della fascia pubocervicale(1-2). La chirurgia ricostruttiva dei difetti del pavimento pelvico sta radicalmente cambiando e i continui progressi della biotecnologia e dei materiali protesici che promuovono la crescita di tessuto connettivo di supporto, ha portato alla nascita e allo sviluppo della chirurgia protesica miniinvasiva anche in questo campo (3). All'interno di questa nuova concezione chirurgica il nuovo sistema transotturatorio per la correzione del prolasso della parete anteriore vaginale, "Perigee", sembra evidenziare molto bene quelli che dovrebbero essere i vantaggi rispetto ad una chirurgia più tradizionale (4-5):

- la miniinvasività

- la riduzione dei tempi chirurgici

- la riduzione del sanguinamento intraoperatorio

- la riduzione delle complicanze intraoperatorie

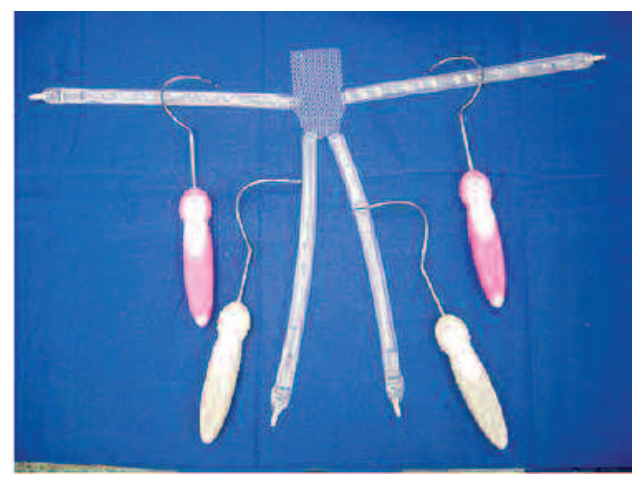

Fig. 2 - Perigee device 
- deep and at the same time tension-free positioning of the mesh.

The Perigee System consists of a central mesh made of large-pore monofilament polypropylene to which are connected four lateral arms, of the same material, which are attached to two sets of helical needles: two needles with a pink handle for the superior passage and two needles with a grey handle for the inferior passage. (Fig.1-2)

The surgeon should hold the superior needle exactly like the helical needle in the TOT out-in procedure, at approximately 45 degrees to the patient's midline. The inferior needle should be held parallel to the patient's midline, but may be angled ventrally to correct the passage. It is very important to remember that the surgeon must angle the inferior needle directly towards the ischial spine. The tip of the needle should be turned towards the surgeon's finger, which should palpate the ischial spine. If this is not done correctly the curve of the needle will push the tip anteriorly towards the pubic bone. If the needle is in the correct plane,

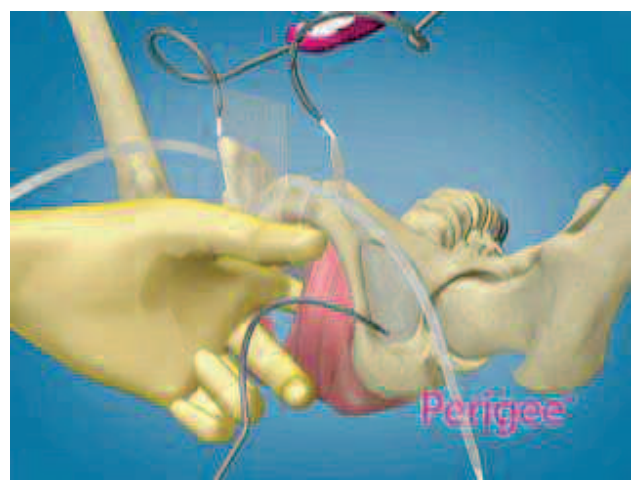

- la più facile riproducibilità della tecnica

- la possibilità di standardizzazione

- il posizionamento profondo ed al contempo tension-free della mesh.

Il "Perigee" è un sistema costituito da una mesh centrale in polipropilene monofilamento macroporoso alla quale sono connessi quattro bracci laterali, dello stesso materiale, che vengono agganciati a due sets di aghi ad elica: due aghi con manico rosa per il passaggio superiore e due aghi con manico grigio per il passaggio inferiore. (Fig.1-2)

L'operatore dovrebbe tenere l'ago superiore esattamente come quello elicoidale della TOT out-in, circa a 45 gradi dalla linea mediana della paziente. L'ago inferiore dovrebbe essere tenuto parallelo alla linea mediana della paziente, ma può avere un'angolatura ventrale per correggere il passaggio. È molto importante ricordare che il chirurgo deve angolare l'ago inferiore direttamente verso la spina ischiatica. La punta dell'ago dovrebbe essere rivolta verso il dito dell'operatore, che dovrebbe palpare la spina ischiatica. Se questo movimento

Fig. 3 - The surgeon should hold the superior needle exactly like the helical needle in the TOT out-in procedure, at approximately 45 degrees to the patient's midline. The inferior needle should be held parallel to the patient's midline, but may be angled ventrally to correct the passage. If the needle is in the correct plane, passage of the inferior needle is as easy and risk-free as passage of the superior needle. 

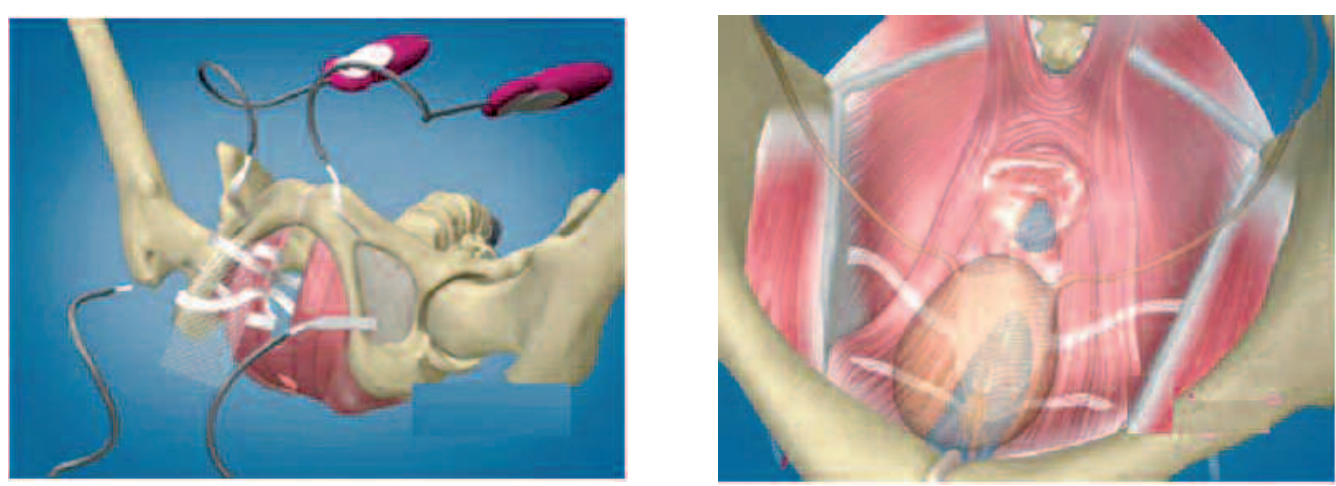

Fig. 4-5 - Insertion of the four arms through the white line of the muscular fascia provides good lateral support without the need for lateral section of the tendinous arch.

passage of the inferior needle is as easy and risk-free as passage of the superior needle. (Fig. 3)

Insertion of the four arms through the white line of the muscular fascia provides good lateral support without the need for lateral section of the tendinous arch. (Fig. 4-5) (6-7). This system offers a faster, easier technique with limited intra-operative bleeding (8-9). non è fatto correttamente l'elica dell'ago spingerà la punta anteriormente verso l'osso pubico. Se l'ago è sul piano corretto, il passaggio inferiore risulta agevole ed esente da rischi tanto quanto il passaggio dell'ago superiore. (Fig. 3)

L'inserzione dei quattro bracci attraverso la linea bianca della fascia muscolare determina un buon supporto laterale senza dover sezionare lateralmente l'arco tendineo. (Fig. 45) (6-7) Questo sistema consente di avere a disposizione una tecnica più veloce, più facile e con limitato sanguinamento intraoperatorio (8-9).

\section{MATERIALI E METODI}

\section{MATERIALS AND METHODS}

We recruited 20 patients with anterior vaginal prolapse, mean age 63.8 years $\pm 11.2 \mathrm{SD}$, mean number of children $2 \pm 0.7 \mathrm{SD}$. Of the $20 \mathrm{pa}-$ tients, 5 were taking hormone replacement treatment (HRT). Ten of the patients had a lateral defect, six a central defect and four a mixed de-
Abbiamo reclutato 20 pazienti con prolasso vaginale anteriore, età media 63.8 anni $\pm 11.2 \mathrm{DS}$, parità media $2 \pm$ 0.7 DS. Delle 20 pazienti, 4 assumevano terapia ormonale sostituiva (HRT). Di queste pazienti 10 presentavano un difetto laterale, 6 un difetto centrale e 4 un difetto misto. Per la 


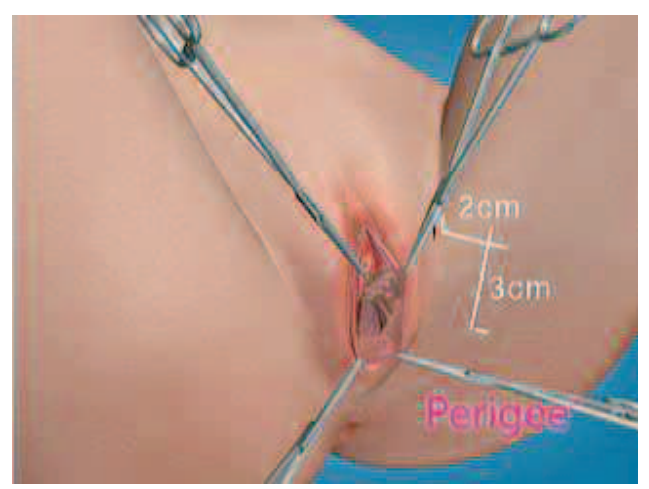

Fig. 6 - Identification of two inferior reference points, situated $2 \mathrm{~cm}$ laterally and $3 \mathrm{~cm}$ inferior to the previous ones, for introduction of the two inferior needles

fect. Prolapse and therapeutic outcome were evaluated using the POPQ system. Before the operation, all 20 patients were suffering from grade III cystocele. Of the 20 women we studied, eight had cystocele associated with grade II-III uterine prolapse, while the other twelve had already undergone hysterectomy. In the eight cases of cystocele with uterine prolapse, we combined the Perigee procedure with a prior colpohysterectomy. Of the 20 patients examined, two had associated stress urinary incontinence, demonstrated clinically, with and without pessary, and urodynamically. Urodynamic tests were carried out on the 20 patients. Preoperative urodynamic evaluation was negative in the 18 patients with cystocele without associated urinary incontinence. The patients with isolated prolapse of the anterior vaginal wall thus underwent prosthetic intervention with the Perigee system and in the patients with associated urinary incontinence,

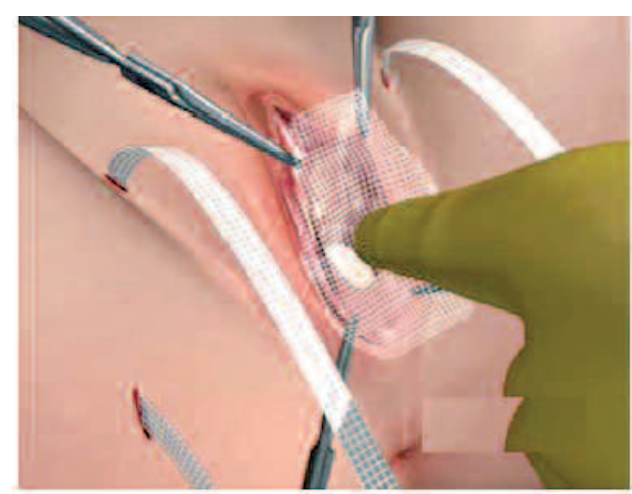

Fig. 7 - Extraction of the four arms through the obturator foramen and correct tension-free positioning of the mesh

valutazione del prolasso e per la valutazione del successo terapeutico è stato utilizzato il sistema POP-Q. Tutte le 20 pazienti presentavano preoperativamente un cistocele di grado III. Delle 20 donne da noi studiate, 8 presentavano un cistocele con associato un prolasso uterino di II-III grado, mentre le altre 12 erano già state precedentemente isterectomizzate. Agli 8 casi di cistocele con prolasso uterino abbiamo, pertanto, associato all'intervento di "Perigee" un primo tempo chirurgico di colpoisterectomia. Delle 20 pazienti analizzate, 2 presentevano un'incontinenza urinaria da sforzo associata, clinicamente ed urodinamicamente dimostrata, con e senza pessario. Alle 20 pazienti sono state eseguite le prove urodinamiche. Le 18 pazienti con cistocele senza incontinenza urinaria associata avevano una valutazione urodinamica preoperativamente negativa. Le pazienti con prolasso della parete vaginale anteriore isolato sono quindi sta- 
the incontinence was corrected at the same time with transobturator positioning of a median suburethral tape.

The Perigee surgical procedure consists of four steps:

a) deep lateral dissection of the vaginal wall until the ischiopubic ramus is reached; this allows use of the ischial spine as a reference for correct passage of the inferior needles.

b) identification of two superior reference points on the genitofemoral fold, located where the fold itself meets a virtual transverse line passing through the clitoris (classic reference point for insertion of the needle for transobturator correction of SUI) or passing through the urethral meatus, for introduction of the two superior needles. Subsequent identification of two inferior reference points, situated $2 \mathrm{~cm}$ laterally and $3 \mathrm{~cm}$ inferior to the previous ones, for introduction of the two inferior needles (Fig. 6).

c) insertion of the four needles through the reference points identified and attachment to the arms of the mesh.

d) extraction of the four arms through the obturator foramen and correct tension-free positioning of the mesh. (Fig. 7)

All the patients received pre-operative antibiotic prophylaxis. The surgical operation was conducted under spinal anaesthesia in eleven cases and under general anaesthesia in nine cases, solely on the basis of anaesthesiological choices. No cystoscopic control was carried out during the Perigee operation. A Foley catheter was in place during the operation and was removed in all pa- te sottoposte ad intervento protesico con il sistema "Perigee" e nelle pazienti con associata incontinenza urinaria si è effettuata in contemporanea la correzione dell'incontinenza con posizionamento di benderella sottouretrale media per via transotturatoria.

La procedura chirurgica "Perigee" consiste in quattro passaggi:

a) dissezione laterale profonda della parete vaginale fino al raggiungimento della branca ischiopubica, che consente di utilizzare la spina ischiatica come repere per il corretto passaggio degli aghi inferiori.

b) individuazione di due punti di repere superiori sulla piega genitofemorale, localizzati sul punto di incontro tra la piega stessa ed una linea virtuale trasversale passante per il clitoride (classico punto di repere per il passaggio dell'ago per la correzione transotturatoria della IUS) o passante per il meato uretrale, per l'introduzione dei due aghi superiori. Successiva individuazione di due punti di repere inferiori, $2 \mathrm{~cm}$ più lateralmente e 3 $\mathrm{cm}$ più in basso rispetto ai precedenti, per l'introduzione dei due aghi inferiori (Fig. 6).

c) inserzione dei quattro aghi attraverso i punti di repere individuati e aggancio con i bracci della mesh.

d) estrazione dei quattro bracci attraverso il forame otturatorio e corretto posizionamento tension-free della mesh. (Fig. 7)

Tutte le pazienti sono state sottoposte a profilassi antibiotica preoperatoria. L'intervento chirurgico è stato eseguito in 11 casi in anestesia spinale $\mathrm{e}$ in 9 casi in anestesia generale, sulla base di scelte esclusivamente 
tients on the first day after the operation. At the end of the operation a vaginal pack was positioned in all patients and left in place for 24 hours.

\section{RESULTS}

The mean duration of the "Perigee" operation was 25 minutes. The mean volume of intra-operative bleeding was $100 \mathrm{cc}$. Mean period in hospital was two days. We reevaluated the 20 patients six weeks, three months, six months, twelve months and eighteen months after the operation. After six weeks and after three months the cystocele was entirely resolved (grade 0) in all 20 patients. After six months the cystocele was resolved (grade 0) in 17 patients, while three had grade I cystocele. After 12 months and after 18 months the cystocele remain grade 0 in 16 patients, while four patients showed grade I cystocele. Our data show no vesical perforation, no haematoma, no significant bleeding and no cases of dyspareunia in the 11 sexually active women. Two vaginal mesh extrusions with a diameter of approximately 2 $\mathrm{cm}$ at the level of the anterior vaginal wall were observed three months after the operation; they were subsequently repaired under general anaesthesia on a day hospital basis with removal of the eroded portion anestesiologiche. Durante l'intervento di "Perigee" non è stato effettuato il controllo cistoscopico. Il catetere vescicale di Foley era in sede durante l'intervento ed è stato rimosso in tutte le pazienti in prima giornata postoperatoria. Al termine dell'intervento è stato posizionato in tutte le pazienti uno zaffo vaginale lasciato in sede per 24 ore.

\section{RISULTATI}

La durata media dell'intervento di "Perigee" è stata di 25 minuti. La quantità media del sanguinamento intraoperatorio è stata di $100 \mathrm{cc}$. La degenza media è stata di due giorni. Abbiamo rivalutato le 20 pazienti a 6 settimane, 3 mesi, 6 mesi, 12 mesi e 18 mesi dopo l'intervento chirurgico. Dopo 6 settimane e dopo tre mesi il cistocele risultava risolto in tutte e 20 le pazienti (grado 0). Dopo 6 mesi il cistocele rimaneva di grado 0 in 17 pazienti, mentre in tre pazienti compariva un cistocele di I grado. Dopo 12 e 18 mesi i cistoceli di grado 0 restavano 16 , mentre 4 pazienti presentavano un cistocele di I grado. I nostri dati non riportano nessuna perforazione vescicale, nessun ematoma, nessun sanguinamento significativo e nessun caso di dispareunia nelle 12 donne sessualmente attive. Si è manifestata una erosione vaginale del diametro di circa $2 \mathrm{~cm}$ a carico della parete vaginale anteriore a 3 mesi dall'intervento ed una erosione a 6 mesi, riparate entrambe in anestesia generale in regime di Day Hospital con rimozione della parte erosa e ri- 
and resuture of the vaginal mucosa. No cases of urinary retention developed, while we detected one case of de novo mixed urinary incontinence at the three-month check-up. The two cases of associated stress urinary incontinence were resolved at the three- six-twelve and eighteen months of check-ups. In 18 cases of cystocele not associated with urinary incontinence urodynamic evaluation was negative at the 18-month checkup with urodynamic parameters substantially unchanged from the pre-operative check-up.

\section{DISCUSSION}

This technique represents an innovation in reconstructive pelvic surgery. Its characteristics of reproducibility and minimal invasiveness appear to afford the possibility of significantly reducing surgical times, intra-operative bleeding, major vascular damage and other complications that can arise in the course of traditional surgery, such as dyspareunia and stenosis of the vaginal canal. It is important to remember that both lateral and central defects can be corrected with this method; it should also be recalled that in tension-free reconstructive prosthetic surgery, resection of the vaginal walls, if carried out, should however be minimal.

In our cases the rate of cure, determined using the POP-Q system for prolapse evaluation, is extremely good, and no major complications, such as haematoma, infection, urinary retention or dyspareunia, were ob- sutura della mucosa vaginale. Non si è sviluppato nessun caso di ritenzione urinaria, mentre abbiamo assistito ad un caso di incontinenza urinaria mista de novo al controllo al $3^{\circ}$ mese. I due casi di incontinenza urinaria da sforzo associata, al controllo a tre, sei mesi e 12 mesi risultavano risolti. In 18 casi di cistocele non associato ad incontinenza urinaria la valutazione urodinamica risultava negativa al controllo del sesto mese con parametri urodinamici sostanzialmente invariati rispetto al controllo preoperatorio.

\section{DISCUSSIONI}

Questa tecnica rappresenta un procedimento innovativo nella chirurgia pelvica ricostruttiva. Le caratteristiche di miniinvasività e la riproducibilità sembrano in grado di ridurre significativamente i tempi chirurgici, il sanguinamento intraoperatorio, le lesioni vascolari importanti e le altre complicazioni in cui si può incorrere con la chirurgia tradizionale, come la dispareunia e la stenosi del canale vaginale. È importante ricordare che con questa metodica è possibile correggere sia il difetto laterale che quello centrale; va inoltre ricordato che nella tecnica chirurgica protesica ricostruttiva tension-free, la resezione delle pareti vaginali, se eseguita, deve essere comunque minima.

Nella nostra casistica il tasso di cura, obiettivato mediante il sistema POP-Q per la valutazione del prolasso, risulta essere estremamente buono, e non si sono verificati casi di im- 
served. Our experience appears to show that transobturator prosthetic correction of cystocele represents a safe, effective and reproducible minimally-invasive surgical technique, which permits adequate restoration of normal anatomy. We believe that this procedure is particularly indicated in cases of major vaginal prolapse (3 grade III) and in cases of recurrence. In view of the limited familiarity with this technique, in terms of experience and cases, nationally and internationally, it is essential to emphasise that the real efficacy and advantages of this procedure should be validated by way of a broader range of case histories and long-term follow-up. portanti complicazioni quali ematomi, infezioni, ritenzioni urinarie e dispareunia. La nostra esperienza sembra dimostrare che la correzione protesica del cistocele per via transotturatoria rappresenti una tecnica chirurgica miniinvasiva sicura, efficace e riproducibile, che consente un adeguato ripristino della normale anatomia. Riteniamo che tale procedura sia particolarmente indicata nei casi di prolassi vaginali importanti ( $\square$ III grado) e nei casi di recidive. Considerata la limitata esperienza e casistica nazionale ed internazionale di tale tecnica, è assolutamente necessario sottolineare che la reale efficacia e i vantaggi di questa procedura, dovranno essere validati da un ampliamento della casistica e da un follow-up a lungo termine.

\section{Author's address for communication:}

chiarabraghin@yahoo.it

Chiara Braghin

via Papa Giovanni XXIII n ${ }^{\circ} 28$

31015 Conegliano Veneto (Tv)

cell 349-6033534 


\section{References}

1 -RICHARDSON A.C., LYONS J.B., WILLIAMS N.L. : A new look at pelvic relaxation. Am J Obstet Gynecol 1976; 126: 568-73.

2 -De Lancey J.O.L. : Anatomic aspects of vaginal eversion after bysterectomy. Am J Obstet Gynecol 1992; 166: 1717-28.

3 -PALMA P., RANE A., RICCETTO C., HERRMANN V., DAMBROS M., TARAZONA A. : Correcion transobturatoria de los cistoceles.

Actas Urologicas Espanolas 2005 gennaio; 89-92

4 -MOORE R. :

Incidence and prevalence of pelvic organ prolapse. In new techniques in pelvic floor reconstruction. Minneapoli Mn, 2004. American Medical System

5 -Manhes H. :

Laparoscopic Retzio-plasty. A new surgical approach to stress incontinence. Int Surg 1996; Oct-Dec; 81 (4): 371-373

6 - DELORME E., DROUPY S., DE TAYRAC R., DELMAS V. :

Transobturator tape (Uratape). A new minimally-invasive procedure to treat female urinary incontinence. Eur Urol 2004; Feb; 45 (2): 203-207

7 -Palma P.C.R., Fraga R. :

Sling Transobturatorio reajustavel: Uma abordagem promissora na Incontinencia Urinaria de esforco. Urologia Contemporanea 2002:4: 146-148

8 -PALMA P.C.R., RICCETTO C.L.Z., FRAGA R., DAMBROS M., THIEL M., BORGES G.M., NETTO N.R. jr. :

Sling transobturatorio: uma nova opcao minimamente invasiva para o tratamento da incontinencia urinaria de esforco.

Urodinamica e Uroginecologia 2002;5 (3) 109-113

9 -Walters M.D., Tullikanga P.K., La Sala C., Muir T.V. :

Vascular injury during tension free vaginal tape procedure for stress urinary incontinence. Obstet Gynecol 2001; 98; 957-959 